\title{
Managing University Research \\ In the Triple Helix
}

Erik Ernø-Kjolhede, Kenneth Husted, Mette Monsted, Soren Barlebo Wenneberg

WP 13/2000

Oktober 2000 
MPP Working Paper No.13/2000 @

October 2000

ISBN: 87-90403-81-9

ISSN: $1396-2817$

Dette working paper er udgivet som del af REMAP-projektet:

REsearch MAnagement Processes under rapid change

Yderligere oplysninger om REMAP kan findes på projektets web-site: www.remap.dk.

Department of Management, Politics and Philosophy

Copenhagen Business School

Blaagaardsgade 23B

DK-2200 Copenhagen $\mathrm{N}$

Denmark

Phone: +4538153630

Fax: $\quad+4538153635$

E-mail: as.lpf@cbs.dk

http:/ / www.cbs.dk/departments/mpp 


\title{
Managing university research in the triple helix
}

Erik Ernø-Kjølhede, eek.lpf@cbs.dk

Kenneth Husted, husted@cbs.dk

Mette Mønsted, mm.lpf@cbs.dk

Søren Barlebo Wenneberg, sw.lpf@cbs.dk

all from

Department of Management, Politics and Philosophy

Copenhagen Business School

Blaagaardsgade $23 \mathrm{~B}$

DK-2200 Copenhagen N

\begin{abstract}
This paper argues the need for a new approach to the management of academic researchers and their research work. It is held that the requirement for a new management paradigm at the universities is accentuated by all the significant challenges in the knowledge production system (described as mode 2, triple helix, post-academic science etc.). The paper not only argues the need for a new management approach but also attempts to sketch an outline of an approach to microlevel management of academic researchers. This approach seeks to strike a balance between autonomy for the academics and organisational steering.
\end{abstract}

Key words: Academic research management, societal demands on universities, balancing autonomy and control, $1^{\text {st }}-3^{\text {rd }}$ order management. 


\section{Introduction}

It has become almost commonplace to observe that the knowledge production system is undergoing significant changes in these years. The prime characteristics of the current and future developments in the world of publicly funded research is an increased articulation of societal expectations concerning the ability of public research to contribute to solving societal problems, wealth creation and other forms of utility.

For state universities in particular, policy developments are leading to fundamental changes. Let us look at a few examples from a Danish context. In 2000 so-called "development contracts" have been signed between universities and the Ministry for Research. These contracts are a brand new management instrument in Denmark and explicitly focus on success criteria and measurements of output in a way never seen before in the Danish university sector. Another recent example of changes at Danish universities is an act adopted in 1999 on inventions at public research institutions. According to this act Danish public researchers are now obliged to inform their employer of potentially patentable or otherwise commercially exploitable research and refrain from publishing for up to two months until the employer has decided whether or not to exploit the research result commercially. (The act transferred public researchers' personal rights to an invention to the institutional level). Changes such as these are far from unique to Denmark. In fact similar changes have been seen in much of the Western world as embodied in the triple helix concept which seeks to describe the efforts to establish an integrated research system that is responsive to social needs and capable of addressing targeted problem areas. In their wake the changes related to the triple helix concept have created managerial challenges both at the societal, institutional, departmental, team and individual levels in the research system.

Publicly funded research at universities and national laboratories is thus now not only forced to face the classic challenge of efficient utilisation of limited resources but also to face the challenge of reaching out to wider society. At the heart of the political desires for change is management. As argued by Ziman (1994, page 272): "if there is a single word that epitomises the transition to 'steady state' science it must be 'management"'. Also Nowotny (1987) sees management as crucial for science policy. Nowotny (1987, page 72) predicts that "the new ethos of science for public policy will be that of scientific managers". However, much of the writing on the triple helix 
concept and the policy talk on research management take a macro or institutional perspective as its point of departure. Little attention is in fact devoted as to how these demands are experienced and may best be carried out by university leaders and researchers in their daily practice in research organisations.

This paper argues that academic research needs a new approach to the management of academic researchers and their work in order to adapt to the ever-increasing focus on application and capitalisation of research. The paper draws upon insights from management of industrial research and modern management theory. Based on this we seek to draw the contours of a possible new model of micro-level management at universities. It is crucial for the new model that management is conceived as a function and not as authority embedded in one person only. The suggested model distances itself from traditional top-down, central decision and control based management by suggesting that modern research management relies on a division of the management activities between the research management and the individual researcher or group of researchers. This division does not make the life of research managers any easier. On the contrary since the division does not lean on formal authority but on such imprecise concepts as values, cognitive frames, communication, autonomy, network and mutual trust, modern research management therefore calls for a dramatic increase in the level of skills and training of many academic research managers.

The paper has the following structure: the first section identifies the developments, which ought to bring the search for a new mode of micro-level research management to the top of the agenda of the stakeholders in academic research. In the second section we suggest a number of ways for the modern academic research manager to deal with the new challenges. Key concepts in the second section are; first to third order management, self-guiding systems and balancing autonomy and control.

\section{Why do universities need a new approach to micro-level research management?}

Universities already have a formal hierarchy of managers. However, by tradition lower level managers close to the individual researchers are often managers by name rather than by fact. In the age of the triple helix this will no longer suffice as 
universities not only face strong pressures for creating new knowledge related to the needs of society but also have to cope with these challenges in an increasingly competitive labour market for knowledge workers. Besides these facts the manager in charge of university academics and their research also has the below challenges to face:

1. The academic tradition is in opposition to management

2. The conflict between the classic academic and the societal perspective on science

3. Increasing complexity of both the research process and the organising between research organisations

Let us take a look at these three challenges in turn.

\subsection{The academic management tradition}

The prime challenge facing a university research manager is that management is not a part of the academic tradition into which researchers have been socialised through their academic training. On the contrary, the norms and values learned by researchers through their academic studies are typically contradictory to management. Mintzberg (1983) e.g. characterises universities as "professional bureaucracies". A professional bureaucracy is decentralised, the professionals control their own activities, are independent ${ }^{1}$ of colleagues and administrative decisions are taken on a collegiate basis. Mintzberg's notion of professional bureaucracies shares many of the characteristics of Weber's concept of direct democratic management (1922 [1982]). Weber's concept presupposes that all members of the group are in principle equally qualified to deal with common matters and problems. Another characteristic is that direct democratic management inherently tries to reduce the extent of authority to a minimum. Although Weber argues that these two characteristics are not necessarily linked it seems that a reason for trying to reduce management to a minimum is the fact that all, at least in principle, are equals in this system. This may create a situation where the person officially in charge may in actual fact be, and feel him or herself to be, the servant of the people he or she is officially in charge of. 
The egalitarian democratic structure has lead a Danish economics professor to make the following succinct comment on the academic research management tradition:

"To many with knowledge of life in a university department, research management in such a place seems as remote as the moon...It is also a fact that the chain of command is very unclear if not blurred. Elected managers have only limited, formal direct influence on research carried out in the departments and the actual direct influence is in most cases even smaller.” [our translation] Hylleberg (1997, page 84).

We would contend that it is not unfair to characterise present research management at many universities as a democratic form of laissez-faire management. It is often invisible, random and unprofessional.

\subsection{The conflict between the classic academic and societal perspective on science}

At the heart of the challenges facing the academic research manager is a clash between two different rationales concerning the purpose of science (Wenneberg, 1999). These rationales are illustrated in the following figure, where the classic perspective is seen to be most influential in basic science in universities whereas the applied, societal perspective is dominant at the policy level and in mission-oriented research funding agencies such as the EU: 
Figure 1: The two perspectives on science

\begin{tabular}{|c|c|c|}
\hline & $\begin{array}{l}\text { The classic, academic } \\
\text { perspective on science }\end{array}$ & $\begin{array}{l}\text { The societal perspective } \\
\text { on science }\end{array}$ \\
\hline $\begin{array}{l}\text { The purpose of } \\
\text { science }\end{array}$ & $\begin{array}{l}\text { To accumulate certified } \\
\text { knowledge as an end in itself }\end{array}$ & $\begin{array}{l}\text { To produce knowledge for } \\
\text { practical application }\end{array}$ \\
\hline Quality evaluated by & $\begin{array}{l}\text { Intra-scientific criteria (reliability, } \\
\text { consistency, originality, } \\
\text { objectivity) }\end{array}$ & $\begin{array}{l}\text { Intra- and extra-scientific criteria } \\
\text { (relevance, utility, economic } \\
\text { impact) }\end{array}$ \\
\hline $\begin{array}{l}\text { The individual } \\
\text { researcher's research } \\
\text { should }\end{array}$ & Be independent and autonomous & $\begin{array}{l}\text { Be managed in accordance with } \\
\text { societal and organisational } \\
\text { objectives }\end{array}$ \\
\hline $\begin{array}{l}\text { The prime source of } \\
\text { control is }\end{array}$ & Peers in the prestige hierarchy & $\begin{array}{l}\text { The (professional) management of } \\
\text { the employing organisation }\end{array}$ \\
\hline $\begin{array}{l}\text { Best possible development } \\
\text { of the institution of science } \\
\text { takes place through }\end{array}$ & Self-organi & $\begin{array}{l}\text { Design by institutional and } \\
\text { political management }\end{array}$ \\
\hline $\begin{array}{l}\text { Images of the nature of } \\
\text { research and researchers }\end{array}$ & $\begin{array}{l}\text { Research is unpredictable and } \\
\text { therefore unmanageable; the } \\
\text { serendipity model; a researcher } \\
\text { can be described as a kind of artist } \\
\text { The individualist perspective: } \\
\text { - The researcher is a "self- } \\
\text { employed" person who } \\
\text { motivates him(her)self } \\
\text { The researcher must be } \\
\text { autonomous and free to set } \\
\text { his or her own agenda for } \\
\text { research: free thinking is the } \\
\text { basis for creativity and } \\
\text { originality } \\
\text { Research is a personal calling } \\
\text { for the few; it is a highly } \\
\text { elitist and unique activity } \\
\text { Researchers are individualists } \\
\text { and loners }\end{array}$ & $\begin{array}{l}\text { Research is purposive and } \\
\text { intentional. Management is } \\
\text { possible as most researchers do } \\
\text { standard research and work with } \\
\text { set methods ("puzzle solving"); } \\
\text { The high-skilled employee } \\
\text { perspective: } \\
\text { - The researcher is an employee } \\
\text { who sometimes needs to be } \\
\text { motivated } \\
\text { The researcher must integrate } \\
\text { his research agenda with the } \\
\text { desires of stakeholders: free } \\
\text { and institutional thinking } \\
\text { - } \\
\text { Research is a professional } \\
\text { calling; it is a craft which can } \\
\text { be taught } \\
\text { Researchers are individualists } \\
\text { and team players }\end{array}$ \\
\hline Typical exponents & $\begin{array}{l}\text { Merton, Hagstrom, } \quad \text { Barber, } \\
\text { Popper, Bush }\end{array}$ & $\begin{array}{l}\text { Fuller, Gibbons et al. Etzkowitz \& } \\
\text { Leydesdorff }\end{array}$ \\
\hline
\end{tabular}

These two perspectives are to a large extent each other's antitheses (although they may and do exist alongside each other). When left unmediated, as it has been the case in many industrialised countries in the last decade, the two perspectives will lead to conflict and a sub-optimal use of resources. Research management has traditionally not gone into these dilemmas, but in light of the mounting potential for a clash 
between the two rationales active research management is becoming increasingly important for organising the frameworks for research in a more efficient way. Modern research management is thus challenged with the need for co-ordinating activities among researchers with different conceptions of what it means to be a researcher. In line with the classic academic perspective the university researcher has traditionally been portrayed as a solitary truth-seeking and independent thinker - the archetypes being Newton and Einstein. As the societal perspective on research becomes more and more influential this picture should today be subjected to a strong revision. The bulk of contemporary research is based on co-operation between several researchers who are not necessarily in the Nobel Prize category individually. Thus the conception of a scientist should now change from being regarded as a 'larger-than-life' individual to that of a high-skilled employee. Yet there are indications that many of the underlying assumptions of the "larger-than-life" perspective are still important in many researchers' self-understanding in academia. This is a self-understanding which leaves little room for management as argued above as the researcher is seen as a selfemployed individual who should be left alone to pursue his or her own ideas. In figure 1 this is referred to as the individualist perspective and contrasted with a competing perspective on the researcher as a high-skilled employee (Ernø-Kjølhede, 1999). It should be emphasised that both ideal types in figure 1 can and do exist as mixes or alongside each other.

\subsection{Increasing complexity}

The development of science shows that in the future, more research will be teamwork oriented. The intensity and the complexity of knowledge are increasing - in the research itself as well as in connection with the succeeding use (i.e. technological products and processes). The demands for professional specialisation are subsequently soaring and the individual researcher is no longer able to keep up-to-date on all relevant areas in his field, but has to form part of groups in which co-operation continuously takes place. Furthermore, researchers have always worked on an uncertain basis. Research has creative and innovative elements, which cannot be predicted in full. You may discover new facts, maybe not. Consequently, uncertainty is an inherent condition in research. Today, the uncertainty also increases due to research contextual conditions such as allocation of resources and research political priorities that influence research fields in a way that cannot be predicted. At the 
political and corporate levels there is e.g. a strong interest in creating programmes that facilitate concrete research co-operation between academic and private research organisations and there is all possible reason to see this as something positive. In this way, research can be more varied, more relevant and easy to utilise - to the advantage of society. This crossing of 'borders' in the research community increases complexity thus necessitating a conscious management of the interfaces. Furthermore, the inspiration from private research organisations also means that a political pressure is put forward to improve management of university research as well.

At the overall level research can be seen as one, large research system (The triple helix idea) and as the intensity of co-operation across institutional, disciplinary and national borders is increasing inside this overall system, there is a need to consider a number of assumptions from neighbouring areas of knowledge - thus adding the uncertainties from these areas to that of your own area. Dealing with these uncertainties necessitates on the one side granting researchers a high degree of freedom to make individual decisions. On the other side it all also necessitates coordination between individual decisions. How this may be done is outlined below.

\section{An approach to micro-level university research management}

The impact of the three challenges for conducting academic research mentioned above means that academic research management can no longer be satisfactorily performed as a discrete, laissez-faire activity. The most important tasks for contemporary academic research managers are:

1. to secure an optimal utilisation of resources (human, financial and technical)

2. balancing individual autonomy and organisational control

3. balancing the two perspectives on science (figure 1)

4. reduce complexity

In this section we will by drawing on insight from management of industrial research and modern management theory outline how modern research management at universities can cater to these tasks. 
Public research is increasingly tied to economic development, as has been the general rule in private companies. Public institutions thus share a need with companies for research management. Research based companies have long recognised the need for managerial influence on the research process. Since the decline of the linear growth model in the late 1960s (Coombs, 1996; Hounshell, 1996) various models for allocating limited resources to create optimum value for the company have been developed and tested. In the 1970s and 1980s the linear growth model was succeeded by a management approach with emphasis on risk reduction through strong management influence on the research process and orientation toward the needs of today's customers (Hounshell, 1996; Roussel et al., 1991; Rosenbloom and Spencer, 1996). The fundamental dictum of corporate research management is that on the one hand, it is recognised that individual researchers should possess a high level of autonomy to preserve the ability of research to renew itself - on the other hand, companies need to maintain control over that freedom to develop their research activities in a long-term company perspective.

Scholars working in the emerging fields of competence and evolutionary theory propose a similar approach. They promote the view that in firms operating in rapidly changing environments strategic management should be understood as a continuous process of designing organisations as adaptive systems. Sanchez (1997, page 940) specifies the objective of this interpretation of strategic management as follows: "the objective [...] is creating and supporting self-managing organisational processes that enables better interpretation of and faster response to complex, dynamic environments and their attendant uncertainties". An essential implication of this way of thinking is that strategic management changes character from a decision and control paradigm to a management paradigm emphasising design of self-guiding systems.

To ensure a proper balance between control and autonomy we suggest to design selfguiding systems which set conditions for individual adaptive processes and in which researchers voluntarily work in accordance with collective goals/organizational needs. The tasks of modern research management are best catered to when the management activity is distributed between several levels. This points in the direction of what we call the three-order concept of management: 
Figure 2: $1^{\text {st }}-3^{\text {rd }}$ order management

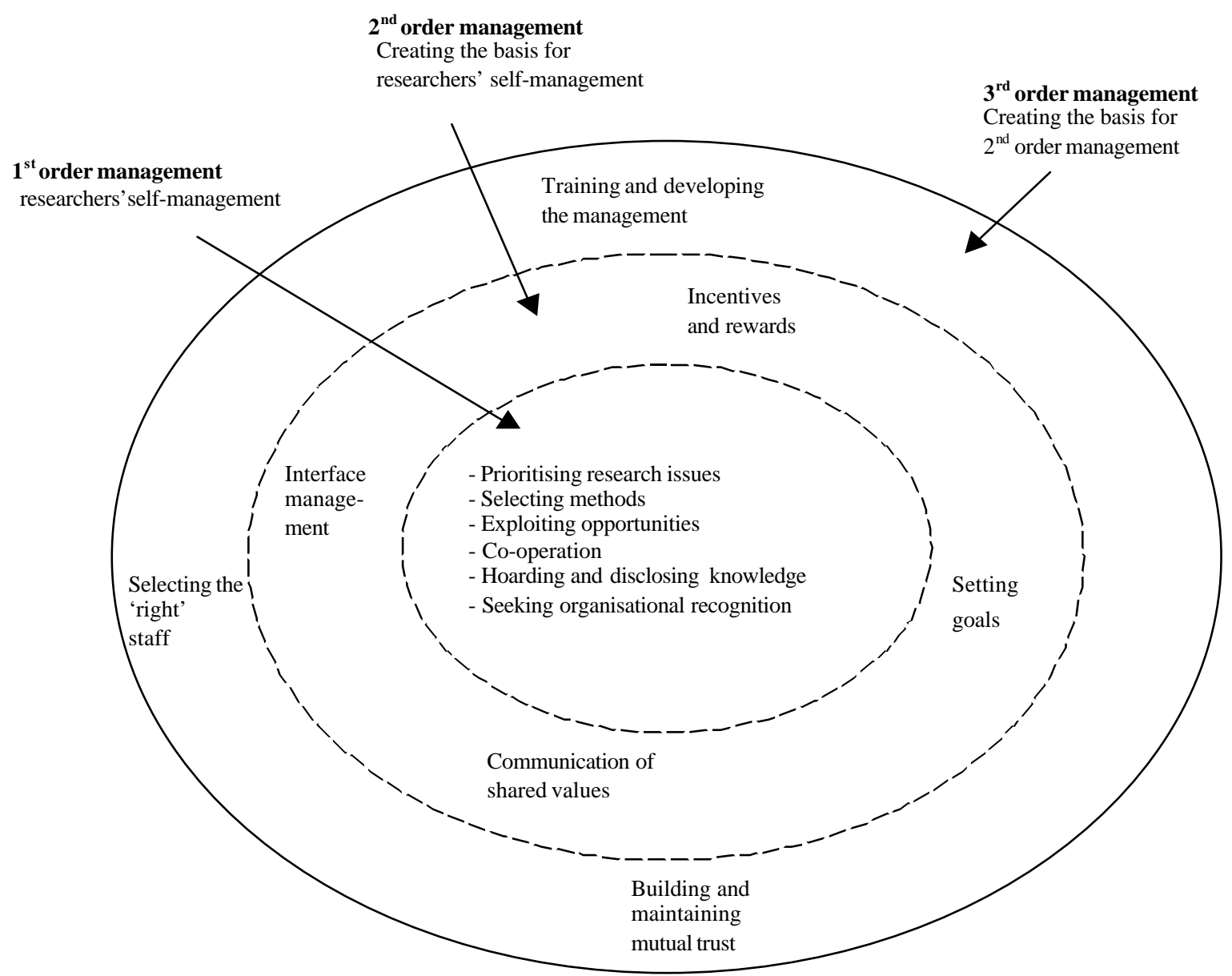

1. The first order is researchers' self-management. Self-management can in this respect be summarised as a good measure of individual freedom to make decisions related to 1) the research process, which methods to apply etc., 2) change of focus of the research, 3) disclosure of knowledge and 4) the use of other sources of knowledge than one's own research. However, these decisions are moderated by demands surrounding the individual researcher. The prime surrounding demands stem from researchers' voluntary submittance to the scientific prestige hierarchy and organisational needs. The key word here is "voluntary" indicating that researchers do not see this submittance as an infringement of their autonomy.

2. The second order management is concerned with conscious management of researchers who are managing themselves at the first order level. Here the focus 
shifts from the individual level to that of the organisational environment. This management form is not about giving orders, as this would make a mockery of individual autonomy and the first order level. Instead second order management entails creating a frame and an environment for the employees' self-guidance of their activities e.g. by means of shared organisational values and norms. This is explained in detail below under the label of "self-guiding systems".

3. The third order concept of management of research is based on building and maintaining mutual trust and shared individual and sub-cultural values and norms in the organisation. It may be said that the two first orders are embedded in third order management. It is a precondition for the second order level that there is an existing, good environment, which enables these management initiatives. Without such an environment it will not be possible to gain acceptance from researchers of organisational needs at the first order level. The most important features of third order management are mutual confidence and staffing. Not only must management at the second order level have confidence in the researcher conducting his research optimally, at the first order level but the researcher as well must have confidence in management's evaluations of the strategic conditions of the surrounding world being correct.

It should be stressed that the apparent linearity in this listing is somewhat misleading. One order does not replace the other. Rather the orders and their basic concepts supplement and exist alongside each other and should be understood as concentric circles. In this understanding management comes both from researcher's selfmanagement (first order) and from overlapping individual and sub-cultural norms in the organisation (second order). And, importantly, the management process is embedded in an atmosphere of mutual trust (third order) functioning as a 'lubricant', which may enable a group of different researchers to act in unison.

The corollary of the above discussion is that research work should on the one hand be managed but on the other hand it should also be led in such a way that researchers are capable of and responsible for managing themselves. This means that the orders the management should influence directly are orders two and three. But through these orders, the first order level is also influenced. Below we focus on how to manage at 
the second order level. Management attempts to create mutual trust at the third order level are thus not addressed.

\subsection{How managers can co-ordinate self-managed individuals}

The design of self-guiding systems necessitates that individual adaptive processes take place in adherence to a joint framework consisting of cognitive frames, typical interpretations, organisational values and goals, etc. (second order level). This framework is intended to function as an alignment mechanism for all thinking, problem solving and decision-making among the researchers in the given system (first order level), be it a university department, industrial lab or inter-institutional project group. The framework functions as an alignment mechanism by supplying researchers with shared patterns for interpretation and priority setting in their individual work.

Through the establishment of such a joint framework the research management can influence the autonomous, individual creation of knowledge by influencing individual decision-making (Husted, 1999). These individual choices do not have the character of fully rational choices. Instead they must be conceived of as learning processes which by means of the individual's limited rationality and the complexity and changeability of the surrounding world is governed by the individual's inadequate interpretations of the surrounding world and his existing knowledge and experience. The research management may, among other things, influence individual adaptation processes governed through this framework by:

1. formulating and communicating organisational goals which researchers can utilise as guidelines for the choice of activities. In this way, the research management can

A. influence the orientation of an individual's research activity

B. influence the variation of the research output

2. influencing the internal, informal communication and in this way shape the cognitive frame by which the individual researcher monitors and interprets his surroundings

3. taking the initiative in and participating in the continuous discussion of what defines good research 
4. creating suitable structures of incentives, which ensure motivation. Both by working with the values and standards of the organisation, but also by giving tangible and intangible (reputation-based) rewards

5. establishing links and facilitating contacts to outside research environments

Summing up, constructing, communicating and constantly negotiating a framework for joint decision-making with researchers may be described as the prime task of the research management. It is also through assuming the role of chief architect and communicator of this framework that the research management is capable of wielding influence and shaping the independent, operational decision-making processes of the various researchers in accordance with the overall goals of the institution or project. Operating under such circumstances the research manager can be described not so much as a manager but rather as a chief integrator of people, goals, inputs and relations in a network of independent parties with both overlapping and different motives and interests (second order level).

\subsection{The new academic research manager}

These abstract and analytical points lead to the question: Which specific qualifications and what knowledge should the future academic research manager possess to ensure that researchers continuously develop and utilise their knowledge both for the fulfilment of individual career goals and in the most beneficial way for the employing organisation? We believe that university research managers should have:

- Disciplinary and interdisciplinary insight as well as an understanding of the positive potential and managerial complexity of interdisciplinary problems

- Visions of the future as well as a strong sense of history and tradition. This applies both to scientific and organisational visions

- Specific management competence. To manage is a specific craft, which can and should be learned

- Have job continuity. It takes time to learn how to become a good research manager and short-term rotations are not suitable. Furthermore, another argument for job continuity is that a research manager should serve as an organisational 
memory of former research achievements and thus play a central role in recognising achievements and creating criteria for what good and bad research is

- An understanding of the triple helix concept and a dedication to making his or her organisation part of a larger knowledge producing and utilising network. This also entails an understanding of political issues and societal needs and concerns about research

- Skills of communication and negotiation

\section{Concluding remarks}

The main thrust of the argument in this paper is that changes in the conditions for doing research in universities have changed in a way which necessitates a much more conscious approach to managing the daily research practice in universities. We have outlined an approach to research management, which seeks to balance individual autonomy and managerial control and we have pointed to some key qualifications which we believe contemporary academic research managers need. However, it should be stressed that management of research is full of dilemmas at many levels of management. Research management is not only tied to the production of knowledge and the creation of conditions for self-management as has been the prime managerial focus in this paper but also to fund-raising and participation in policy discussions about research programmes, research ethics etc. Research managements thus also have the task of relating to research policy signals and other surrounding conditions and adapting their organisations in the best possible way to fit the demands of the resource-controlling surroundings. However, it is argued in this paper that in terms of the management of researchers and concrete research work, managerial influence should be exerted at what we call the second and third order levels. We would contend that management at these levels does not obstruct but rather facilitates researcher's self-management and professional development. Along these lines it may also sometimes be the task of managers to try to shelter researchers from short-term political or corporate whims. In this way, modern research management becomes despite what many believe - a defence of the individual researcher's autonomy and self-determination. 
${ }^{1}$ It may be argued that in the job structure at universities only professors and associate professors are truly independent since $\mathrm{PhD}$-students and assistant professors are only temporarily employed and supervised by the group of professors and associate professors.

\section{References}

Cohen, Laurie, Joanne Duberley and John McAuley, (1999), "Fuelling discovery or monitoring productivity: Research scientists' changing perceptions of management", Organisation vol. 6(3), pages 473-497.

Coombs, Rod (1996), "Core competencies and the strategic management of R\&D", in Belcher, Hassard and Procter, $R \& D$ decisions: strategy, policy and disclosure, pages 24-41, Routledge, London.

Ernø-Kjølhede, Erik (1999), "The Coming of Age of the Danish Research Manager”, MPP Working Paper 5/99, Copenhagen Business School.

Etzkowitz, Henry and Loet Leydesdorff (1998), “The Endless Transition: A Triple Helix of University-Industry-Government Relations", Minerva vol. 36, pages 203-208.

Gibbons, Michael et al (1994), The New Production of Knowledge - The Dynamics of Science and Research in Contemporary Society. (Sage, London).

Hagstrom, Warren O. (1965), The Scientific Community (Basic Books Inc, New York).

Hicks, Diana (1995), "Tacit Competencies and Corporate Management of the Public/Private Character of Knowledge", Industrial and Corporate Change Vol. 4, No. 2, pages 401-424, Oxford University Press.

Hounshell, David A. (1996) "The Evolution of Industrial Research in the United States. Engines of Innovation", Harvard Business School Press, Boston.

Husted, Kenneth (1999), "Between autonomy and control: The role of industrial researchers' decision-making", MPP Working paper 11/99, Copenhagen Business School.

Hylleberg, Svend (1997), "Forskningsledelse på et samfundsvidenskabeligt universitetsinstitut", in the anthology Den vanskelige balance. En bog om forskningsledelse. Akademiet for de tekniske videnskaber, Lyngby.

Mintzberg, Henry (1983), Structure in Fives. Designing Effective Organizations, (Englewood Cliffs, N.J. Prenticehall).

Nowotny, Helga (1987), “A New Branch of Science Inc”, In Brooks, Harvey and Chester L. Cooper, Science for Public Policy (Pergamon Press, Oxford). 
Randle, Keith and Frank Currie (1996): "R\&D strategy and the implications for management control", in Belcher, Alice, John Hassard and Stephen J. Procter $R \& D$ decisions: strategy, policy and disclosure, pages 78-100, Routledge, London.

Rosenbloom, Richard and William Spencer (1996), “Technology's Vanishing Wellspring. Engines of Innovation”, Harvard Business School Press, Boston.

Roussel, Phillip A, Kamal Saad and Tamara J. Erickson (1991), "Third generation R\&D”, Harvard Business School Press, Boston.

Sanchez, Ron (1997), "Strategic Management at the Point of Inflection: Systems, Complexity and Competence Theory", Long Range Planning, Vol 30, pages 939-946.

Smith, Howard L. and John Tuttle (1988), "Managing research scientists: problems, solutions and an agenda for research", Journal of society of research administrators, vol. 20. No.1.

Weber, Max. 1982 [originally published in 1922], Makt og byråkrati (Gyldendal Norsk Forlag, Oslo).

Wenneberg, Søren Barlebo (1999), Den nye videnskab - Et studie af videnskab under forandring (Samfundslitteratur, Copenhagen).

Ziman, John (1994), "Prometheus Bound. Science in a dynamic steady state", Cambridge University Press, Cambridge. 